\title{
The Art of the Accident: Paul Virilio and Accelerated Modernity
}

\author{
Steve Redhead
}

One urgent part of a reconstructed theoretical social and human sciences project in the twenty-first century is to conceptualize anew the 'socio-technologies of connection, resilience, mobility and collapse in contemporary cities' [1] especially in the wake of 9/11, 2001, and 7/7, 2005, all that has followed those events (Ali 2005; Armitage 2005; Conley 2005; Kureishi 2005; Thrift 2005; Virilio 2005a; Virilio 2005b; Virilio 2005c; Virilio 2005d). In this essay we consider critically one example of a theory of the 'accident' - the network failure or collapse or catastrophe or breakdown in what we term here accelerated modernity. That theory is provided by the French urban and cultural theorist Paul Virilio. Virilio's theory of the accident is relatively little known and even less discussed. He is also a figure whose oeuvre has been generally imported into the English speaking academic world as essentially another, albeit quirky, complementary element in contemporary social theory following on from other French theorists such as Jean Baudrillard, Jacques Derrida, Gilles Deleuze and Michel Foucault, when in fact Virilio has accurately characterized himself over the years as explicitly against sociology and, moreover, for, as he has put it, war and politics (Der Derian 1998; Armitage 2000; Redhead 2004a; Redhead 2004b). Moreover, Virilio's consistent influences over the years have been photography, Maurice Merleau-Ponty's phenomenology, Gestalt psychology, stained glass painting and anarchistic Christianity [2], a very different intellectual background to the 'poststructuralists' and 'postmodernists' with whom he is often misleadingly bracketed. Alan Sokal and Jean Bricmont (2003), in their ill-conceived 'expose' of the supposed scientific inadequacies of 'French postmodernism' and 'postructuralism', subject Paul Virilio to withering attack (the Virilio chapter is Chapter 10 in the second English edition) alongside Jacques Lacan, Julia Kristeva, Bruno Latour, and Felix Guattari amongst many others. Unfortunately for Sokal and Bricmont's project, Paul Virilio has little in common with such figures other than nationality or Parisian residence. Indeed, as we shall see in this essay, Virilio has gone further with this self-labeling process and described his own distinct intellectual enterprise as that of a critic of the art of technology (Redhead 2004a). His theory of the accident, then, not surprisingly involves what we call here an aesthetics of the accident. Virilio however, in providing a perspective on the art of the accident in our increasingly accelerated and dangerous modernities, falls short of what is required in the contemporary urban sociological project. What is required, more generally, is in fact a reinvigorated sociology, not merely an art, of the accident.

\section{The Art of the Accident or the Accident of Art}

Paul Virili [3], French theorist of 'urbanisme' extraordinaire and so-called high priest of speed, has been dropping logic bombs on us for over thirty-five years. In these highly idiosyncratic tales of accelerated culture, or what we have elsewhere called accelerated modernity the speed of mass communications as well as the speed of 'things' is what counts (Redhead 2004b). In this scenario we have all, to some extent or other, become historians of Virilio's instant present where immediacy, instantaneity and ubiquity rule. But this is not the whole story of either Paul Virilio or accelerated modernity. 
Paul Virilio is now in his eighth decade. He was born in France in 1932 of an Italian father and French Catholic mother. He has retired from his only academic position as Professor of Architecture at the Ecole Speciale d'Architecture in Paris, France, a post he had held since the late 1960s, after being elected by the students in the wake of the events of 'May 68'. On retirement he was nominated Emeritus Professor. Armed with his senior citizen card he moved from Paris to La Rochelle on the Atlantic coast of France, a considerable upheaval for someone like Virilio who suffers from claustrophobia and rarely travels. He retired, he said at the time, to write a book on, in his own words, 'the accident', a project he had in mind for over ten years. His haphazard progress towards the academy through the 1950s and 1960s was unusual, to say the least, and included a period where he spent his time obsessively photographing hundreds of the German bunkers on the North Atlantic coast of France which date from the Second World War, a conflict which had scarred him as a young man, and a spell where he trained as a stained glass painter working eventually with Braque and Matisse. His ultimate claim to international fame is that he has over many years developed a theory of speed, technology and modernity which, whatever its flaws, is worth taking seriously, even if it is ultimately jettisoned by its once enthusiastic users. This theorizing of speed and modernity alone marks him out as a major contemporary thinker. As a mark of his growing influence in the theoretical development of human and social sciences throughout the globe in the twenty-first century the Virilian idea of the 'dromocratic condition' [4] displacing the notion of 'postmodern condition', has become increasingly popular amongst cultural theorists in the international academy. His idea of the 'function of the oblique', a utopian radical theory of architectural space developed with French architect Claude Parent in the 1960s, has also started to receive the attention it now deserves in the overall assessment of Virilio's life and work (Armitage 2000; Redhead 2004a; Redhead, 2004b). But it is his little known and barely discussed theory of the accident which should interest those involved in the urgent discussions around urban vulnerability and network failure in the twenty-first century. The idea of a global 'dromocratic condition' comes, in fact, from Virilio's short-lived career as a self-styled 'dromologist' in a few short but quite well-known writings in the 1970s (Redhead 2004a; Redhead 2004b). The 'society of speed' that this work analyzed, was never actually part of a fully formed conceptual apparatus and Virilio soon moved on to other topics and ideas in the maelstrom of the neoliberal 1980s. The idea of the theory of the accident on the other hand, though full of problems, is a more sustained part of his recent oeuvre and has been in genesis since at least the early $1990 \mathrm{~s}$ as Virilio has continued to accelerate his output of rapid, short books and distinctive, idiosyncratic interviews (Virilio and Petit 1999; see, for instance, the collection of interviews in Armitage, 2001; and also Virilio and Lotringer 2002; Virilio and Lotringer 2005).

There are conflicting interpretations of Virilio's theorizing in the parts of the academic world which have bothered to consider his work but essentially Virilio's contention is that the speeding up of technologies, especially communications technologies like the internet and e-mail, have tended to abolish time and distance. Speed, for Virilio, has had a largely military gestation. The way in which mass communication has speeded up at the same time has meant, in his view that old-fashioned industrial war has given way to the information bomb (an idea which he takes from Albert Einstein, another major lifelong influence on Virilio) or information war. As military conflict has increasingly become 'war at the speed of light' (see Redhead 2004a for a characterization of all of Virilio's work as theory at the speed of light) - as he labeled the first Gulf War in the early-1990s - the tyranny of distance in civilian as well as military life has almost disappeared. This does not mean that there is no deceleration, or slowness, though. Inertia, or better still what Virilio termed 'polar inertia', has set in for even the supersonic airplane traveler or highspeed train devotee.

As we have already noted, Paul Virilio eventually left his post in academia to write a long-planned book on what he has called the accident, a concept which has over the last decade become more prevalent in his thinking and published work. Crucially, though, the same phenomena of speed and war are different today in Virilio's view than they were when he first started writing about them in any sustained manner in the 1970s and 1980s. He has contemplated this change in a virtual conversation with interviewer Carlos Oliveira in the mid-1990s where he related the issue of the contemporary situation to the general arguments he had been making for a decade or more about the consequences of what he has variously termed 'accelerated temporality' and the 'acceleration of our daily lives':

This is because we are witnessing a radical break; it is not my thinking that has become radical, the situation itself has radicalized beyond measure. The end of the bloc-oriented confrontation between East and West, the transition from the industrial to the INFORMATIONAL mode of production, the globalization that is being achieved through the telecommunication networks and the information (super)highways - all these developments raise grave questions." (Virilio and Oliveira 1996) 
For Virilio the 'grave questions' are increasingly explored through the notion of the accident in his writings during the 1990s and into the twenty-first century. The term accident though, in Virilio's use and specialized terminology, is a complicated and ambiguous notion. Here, as frequently happens elsewhere in Virilio's original French language writing and speaking, the English translation oversimplifies by connoting merely a catastrophic event rather than the deeper philosophical reference to accident and substance and the phenomenological and existentialist debates Virilio inherited from those he listened to (the likes of Maurice Merleau-Ponty, Vladimir Jankelevitch and Jean Wahl) as a student at the university of the Sorbonne in Paris in the early 1960s. Virilio (Virilio and Petit 1999), for his part, has emphasised that:

\begin{abstract}
For the philosopher substance is absolute and necessary, whereas the accident is relative and contingent. So the accident is what happens unexpectedly to the substance, the product or the recently invented technical object. It is, for example, the original accident of the Challenger space shuttle ten years ago. It is the duty of scientists and technicians to avoid the accident at all costs...In fact, if no substance can exist in the absence of an accident, then no technical object can be developed without in turn generating "its" specific accident: ship=ship wreck, train=train wreck, plane=plane crash. The accident is thus the hidden face of technical progress...one thing that must be considered here is the preponderance and role of the speed of the accident, thus the limitation of speed and the penalties for "exceeding the speed limit". With the acceleration following the transportation revolution of the last century, the number of accidents suddenly multiplied and sophisticated procedures had to be invented in order to control air, rail and highway traffic. With the current world-wide revolution in communication and telematics, acceleration has reached its physical limit, the speed of electromagnetic waves. So there is a risk not of a local accident in a particular location, but rather of a global accident that would affect if not the entire planet, then at least the majority of people concerned by these technologies...It is apparent that this new notion of the accident has nothing to do with the Apocalypse, but rather with the imperious necessity to anticipate in a rational way this kind of catastrophe by which the interactivity of telecommunications would reproduce the devastating effects of a poorly managed radioactivity - think about Chernobyl. (Pp. 92-3)
\end{abstract}

The nature of the accident, according to Virilio (Virilio and Oliveira 1996), has changed, and changed speed and everything else in its wake:

The information revolution which we are currently witnessing ushers in the era of the global accident. The old kind of accidents were localized in space and time: a train derailment took place, say, in Paris or in Berlin; and when a plane crashed, it did so in London or wherever in the world. The catastrophes of earlier time were situated in real space, but now, with the advent of absolute speed of light and electromagnetic waves, the possibility of a global accident has arisen, of an accident that would occur simultaneously to the world as a whole.

Despite the fact that the information revolution has not had a great deal of effect on Virilio himself - he uses the internet only rarely, he has at times almost given up watching television - he has said that he does regard cyberspace as a new form of perspective. Our world is a 'cybermonde' according to Paul Virilio. Especially through cyberspace, for Virilio, history has hit the wall of worldwide time where with live transmission, local time no longer creates history, where, in his view, real time conquers real space, producing what he calls a time accident, which he sees as an accident with no equal. According to Virilio (Virilio and Oliveira 1996), speeding up has meant reaching the limit of speed, that of real time:

A possible symptom of this globalization, of the eventuality of such an accident, was the stock exchange crash of 1987 . We will no longer live in local time as we did in the past when we were prisoners of history. We will live in world time, in global time. We are experiencing an epoch that spells the international, the global accident. This is the way I interpret simultaneity and its imposition upon us, as well as the immediacy and the ubiquity, that is, the omnipresence of the information bomb, which at the moment, thanks to the information (super)highways and all the technological breakthroughs and developments in the field of telecommunication, is just about to explode.

\title{
| The Accident of September 11
}

The 9/11 event has been cited by Virilio as an example of his theory of the 'accident of accidents', a generalized accident occurring everywhere at the same time, live on global television and the internet. He admitted to Sylvere Lotringer shortly after the attacks on New York and Washington that 'the door is open' with what he called 'the great attack' and furthermore that he saw New York as 'what Sarajevo was' when 'Sarajevo triggered the First World War' (Virilio and Lotringer 2002). On September 11, 2001, Virilio's earlier prophecy in his work of the 1990s about 
a generalized accident or total accident seemingly came tragically true as a small, tightly knit group of men, armed only with Stanley knives, were seen to have taken over the cockpits of the hijacked planes and flew jet airliners with masses of fuel into the highly populated buildings of the World Trade Center with the loss of nearly 3,000 lives and the destruction of several buildings (including the twin towers) in the heart of the financial center of American (and arguably world) capitalism. The beginning of this post-Cold War age of imbalance as Virilio has called it, was as he said at the time of the first, 1993 attack on the twin towers (after which, bizarrely, he was called on as a consultant) seen in a new form of warfare - the accident of accidents, or the 'Great Accident'. The 1993 attack was precipitous for Virilio (2000):

\begin{abstract}
In the manner of a massive aerial bombardment, this single bomb, made of several hundred kilos of explosives placed at the building's very foundations, could have caused the collapse of a tower four hundred metres high. So it is not a simple remake of the film Towering Inferno, as the age-conscious media like to keep saying, but much more of a strategic event confirming for us all The Change In The Military Order Of This Fin-De-Siecle. As the bombs of Hiroshima and Nagasaki, in their day, signaled a new era for war, the explosive van in New York illustrates the mutation of terrorism. (P. 18)
\end{abstract}

Virilio (2000) noted at the time of the 1993 World Trade Center attack by another small group of terrorists that the perpetrators of such acts 'are determined not merely to settle the argument with guns' but will 'try to devastate the major cities of the world marketplace.' Within eight years a slightly larger group of Islamic fundamentalist terrorists had indeed apparently done so (Ruthen 2002). Many of the features of what Virilio (2000) sets out in a contemporaneous essay on the 1993 World Trade Center attack being on the cards for the future of humanity, were to be put into practice with exactly the predicted effect of the devastation of a world city on September 11, 2001. In fact, ironically, 'Towering Inferno' images probably were rife in the minds of many of the watchers of the 9/11 'accident'. In Virilio's (2002) own book length musings after September 2001, implicitly about the 9/11 attack, entitled [5] Ground Zero, he has explicitly claimed that as the September 11 twin towers attack was being 'broadcast live many TV viewers believed they were watching one of those disaster movies that proliferate endlessly on our TV screens' and that it was only 'by switching channels and finding the same pictures on all the stations that they finally understood that it was true'.

Aesthetically 9/11 was taken as an 'art of terrorism' in some quarters. Virilio (2002) quotes the avant-garde electronic composer Karlheinz Stockhausen as saying it was 'the greatest work of art there has ever been'. Seemingly unknown to Virilio, the Brit-artist Damien Hirst, too, claimed, in the British media, that those responsible for September 11 should indeed be congratulated because they achieved 'something which nobody would ever have thought possible' on an artistic level. The event was in 'bad boy' Damien Hirst's view 'kind of like an artwork in its own right... wicked, but it was devised in this way for this kind of impact" and "was devised visually" (Guardian September 20, 2001).

\title{
| Towards a Sociology of the Accident
}

As we argued at the beginning of this essay, although aspects of the work surrounding the art of the accident might be instructive, what is needed in future theoretical developments in the social and human sciences is a move towards a sociology of the accident. In this part of the essay we can indicate very briefly a starting point for what is required in this enterprise. As we have seen, for Virilio one of the problems of the highly mediatized modernities we inhabit today is that 'attack' and 'accident' are increasingly indistinguishable. We are unsure whether we are experiencing (terrorist) attack or system or network failure when we regularly consume news of events in the media, especially since the watershed events of $9 / 11$ and the subsequent 'war on terror', itself a kind of mediatized never ending 'live' World War IV. The SARS crisis in China, Hong Kong and Canada, BSE scares in North America, train crashes in North Korea, plane crashes in the Middle East, electricity power failures in the USA, UK, Australia and mainland Europe to take some recent random examples are cases where an initial denial of terrorist attack shifts the 'blame' to technical failure of systems (in other words a 'real' accident) in such a way that the event is played down. It is only an accident proclaims the news reader after a few days hype, and therefore everyone can breathe a sigh of relief. What is actually needed is a concentration on the systems and the failure. 9/11, for instance, could be seen as a much an instance of systems failure as 'attack': failure of intelligence (CIA, FBI), governance (failure to act earlier against Al Qaeda), security (airport, airline), transport (aircraft), military (patrolling of skies) and so on. 
Accident, along with elements of its philosophical make up as envisaged by Virilio, may be one of the concepts necessary to understand better the modernities and mobile city cultures of the twenty-first century globe. But the social science in which the sociology of the accident is urgently necessary is itself a reconstructed urban sociological project; a sociology as John Urry has put it 'beyond societies'. We need, instead, a new sociology of mobilities, of what we might call the mobility of modernities around the globe, especially of mobile city cultures. In a world of mobile city cultures the 'city is already there' (Virilio 2005a:) echoing Virilio's 'mental map' view of his own city, Paris (p. 5). As Virilio (2005a) puts it, 'Paris is portable' (p. 5). After 9/11, too, Virilio (2005a) claims that 'the tower has been motorised' and the 'very high building has become mobile' (p.18).

John Urry (2003), has rightly argued, in contemporary sociology the 'global' has been insufficiently theorized. One of the contributions Virilio has made more generally to thinking about modernities is to raise questions about the shrinking of time and space and the effect of the war induced technologies on the speeding up of that process: in other words, to thinking about the global anew. Virilio's development of the philosophical idea of the 'accident of accidents' (and it is the ancient notion that 'time is the accident of accidents' that Virilio is fond of quoting) is one way of rethinking the global, specifying as he does that it is the new communications technologies which have created the possibility of an accident that is no longer local but global; in other words, that would occur everywhere at the same time. Virilio (Virilio and Petit 1999) has stressed that 'time is the accident of accidents' and that 'we have reached the speed of light with e-mail, interactivity and telework' and that is why 'we are creating a similar accident'. An event such as 9/11, eliding accident and attack, was an example of a world wide accident because it was being screened live as it happened in real time all around the globe. That said, the theorizing of the accident by Virilio, though suggestive and (in his own phrase which he likes to use to describe his personal intellectual method and enterprise) 'implicit', is often at such a level of generality that it is not particularly helpful for a rigorous sociology of the accident. Though Virilio's language sometimes appears to import what John Urry (2003) describes as the 'new physics' into the equation of shrinking time and space, there is relatively little evidence of Virilio in actuality standing at the cutting edge of these contemporary breakthroughs in science. As other social theorists claim, it is better to view his work, alongside comparable theorists such as Jean Baudrillard, as a 'poetics' not a form of physics (Cubitt 2001). John Urry argues cogently that the social science enterprise of the twenty-first century which seeks to recruit the thinking of chaos and complexity from 'natural' sciences needs to conceive of systems which are always combining success and failure and are constantly on the edge of chaos. One of the reasons why the 'intellectual impostures' project of the physics pranksters Alan Sokal and Jean Bricmont (2003) attacking Virilio and others is so ill-judged is that it has not caught up with the 'complexity' of science today, never mind the contemporary complexity of theory in the human and social sciences. These systems which John Urry talks about are systems where Virilio's idea of the accident, a kind of built in component of the constant invention of new technologies, is integral. They are part of what we have called elsewhere dangerous modernity which requires an understanding of theory at the speed of light but also a great many more conceptual resources to better capture its global complexities (Redhead 2004a; Redhead 2004b). But even if this aesthetics of the accident is a necessary condition, it is certainly not sufficient. The sociology of the accident, in this view, needs to take into account thinking around the art of the accident but also clearly needs to move beyond it.

\section{The Accident Museum}

What can be said then, of a positive nature, about Virilio's contribution to a theory of the accident, catastrophe, network failure or breakdown in today's mobile city cultures? First, it is important to take Virilio's self-labeling seriously. He is by his own consistent admission 'a critic of the art of technology' and an overview of his life and career leave us in no doubt that he is an 'artist' rather than a social theorist in any conventional sense (Redhead 2004a; Rehead 2004b). He is a high modernist, without connection to the postmodernist and poststructuralist social theorists with whom he is routinely categorized and compared. Second, Virilio has had in mind for many years the development of what he calls a 'museum of accidents' to further aesthetically display his theory of the accident. In both these senses Virilio is closer to Damien Hirst and Karlheinz Stockhausen when they take the controversial view that an event like $9 / 11$ is an aesthetic question. They are all involved, from different perspectives, in the enterprise of the art of the accident. They are artists rather than social theorists.

By the beginning of the new century it was the visual art of computer games which probably had most resonance 
at least amongst the younger citizens of the 'collective world city' who were glued to their television screens as the planes crashed into the World Trade Center in New York on September 11, 2001 (Featherstone and Lash 1999). Remarkably, a Microsoft Flight Simulator 2000 computer game, which some commentators feared had been used by the hijackers of the planes, at least in part, to practice for their suicide mission, was on sale at the time of the event, retailing in world high street stores at about $\$ 80$. It was withdrawn rapidly in the wake of the information, and moral, panic after $9 / 11$ but its basic programme included the capacity of would-be pilots to pretend to crash Boeing $757 \mathrm{~s}$ and $767 \mathrm{~s}$ (the planes used in the actual attack on $9 / 11$ in New York) into the World Trade Center. The graphic images of planes embedded in the higher parts of the towers in the game were uncannily like the moment of impact of the hijacked planes flying into the World Trade Center captured live on television and the internet for a global audience of billions. It is thought by some investigators that the hijackers who flew the planes into the World Trade Center on 9/11 had indeed learned to do so by playing on such simulation systems because of their closeness to 'reality'. In another game, WTC Defender, also quickly withdrawn after the September 2001 event, players could pretend to shoot down pilots as they attacked the World Trade Center.. If an aircraft got through, the buildings blew up. The game had been available to download over the internet.

The links between such 'new media' (computer games, information technology and so on) and the events of accident/attack which Virilio has analyzed (both the 1993 and 2001 World Trade Center catastrophes, for instance) is obviously of interest to students of Virilio given his idiosyncratic focus on the relationships between war, cinema and photography, though we do not have space to fully consider this focus here (see Redhead 2004a). However the significance of 9/11 in assessing Virilio's notion of the accident is more complicated than it might appear. For Virilio, unlike other French theorists of the image such as Gilles Deleuze, the cultural forms of cinema and television actually have nothing in common. Indeed Virilio has, on the contrary, argued the historical case that video technologies and what he calls technologies of simulation have been used for war (Redhead 2004a; Redhead 2004). In Virilio's version of the development of the logistics of perception, video was created after the Second World War in order to radio control planes and aircraft carriers. Further, Virilio has insisted that video came with World War II and it took twenty years after that conflict before it became a means of expression for artists. Nevertheless, Virilio has also noted that it is television (an old, or even dead, media) which is for him what he has to date constituted the actual museum of accidents. For years he has been reportedly planning to set up what he has termed a 'museum of the accident', first in Japan, in the 1980s, appropriately the home of the new technologies of the media, and then in other countries. For Virilio, television's art is in fact to be the site where all accidents happen. But for him it also is its only art. Television has for Virilio (Virilio and Petit 1999) already died:

I would say that television is already dead with the advent of multimedia. It is clear that interactivity is the end of television. I would like to say that the example of television is already outdated. Just as photography gave rise to cinematography, video and television are today giving rise to infography. Television is already a surviving form of media. (P. 46)

The accident museum, or museum of accidents, in Virilio's phrase, certainly preserved for posterity the attacks of 9/11 and enables us to look at Virilio's thinking on the accident with the backdrop of the 'live' television pictures of the New York catastrophe, but Virilio has already started to give up on television as a cultural form (a medium he confesses he no longer watches much himself). He has gone on record as saying that:

I think that the drilling of the gaze by television has gone so far that it is no longer possible to straighten out the situation in one hour. That being said, I am not opposed to showing catastrophes or accidents, because I believe a museum of accidents is necessary. (On this subject, remember that the tape of the Rodney King affair has been put in a museum.) However, I think that television has become the advertising or propaganda medium par excellence. We saw this during the Gulf War, with Timisoara, and we see it every day. Honestly, I am beginning to give up on television. I can no longer tolerate this kind of drilling. It would take the invention of another kind of television, but I believe it's too late. I think that there will be innovation with the new medium but not in the old one. The old medium has gone all the way to the end, which is to say to ITS end. In my opinion television is gone, but not video' (Virilio and Petit 1999:47).

So for Virilio the accident museum exists. He claims to have come across it and it is a TV screen, even if this particular form of technology is on the way out. The requirement of the accident or catastrophe as media event, as 9/11 showed only too well, is the urgency of the screening of the phases of the event 'live'. Television certainly still does still fulfill this requirement.

For Virilio though, what really counts is not so much the technology itself but the need to show what he sees as fallibilism in scientific and technological development in what is more and more an accelerated modernity filled with 
danger (Redhead 2004b). The demand by Paul Virilio is for our global culture to go beyond an ideology of progress, linear and interrupted, excluding the importance of the mishap or the beneficial mistake. To expose the accident, to exhibit the accident, in the accident museum is the crucial task for Paul Virilio the artist. As artist and exhibition creator, the job is to expose the unlikely, to expose the unusual and yet inevitable, in recognizing the symmetry between 'accident' and 'substance'. The accident museum is necessary in Virilio's thinking in order to preserve for posterity the collapsing buildings, high speed plane crashes and other accidents (or attacks) of accelerated modernity.

As a self-proclaimed critic of the art of technology (rather than a conventional social theorist) Virilio, true to his word, jettisoned the televisual form and settled for the art gallery in his quest to preserve $9 / 11$ along with hundreds of other disasters, catastrophes, urban network failures, crashes and explosions for his own real life museum of accidents. A little over a year after 9/11 Virilio (2003) helped to create the accident museum's first concrete realization in a major French contemporary art exhibition (officially labelled 'Ce Qui Arrive' in France), translated as Unknown Quantity in the English version of the catalog which included diverse textual commentary on the theory of the accident by Virilio as well as hundreds of photographs and other artefacts. Virilio created the exhibition with a number of other artists at the Fondation Cartier pour l'art contemporain in Paris (opening in November 2002, closing in March 2003) explicitly incorporating photographic, video and other visual material from the event known as 9/11 as well as assorted plane crashes, earthquakes and high rise collapses from all over the world. Virilio, in the main, provided the concepts for this pioneering art exhibition while curator Leanne Sacramone mapped them onto a series of artworks. As an addition to the catalog of the exhibition Virilio interviewed Svetlana Aleksievich, the author of a book about Chernobyl victims and witnesses. Virilio's emerging ideas on the accident formed the text of the catalog's long introduction, under subheadings such as: the invention of accidents; the accident thesis; the museum of accidents; the future of the accident; the horizon of expectation and the unknown quantity. According to one hip contemporary art commentator on the Paris exhibition, 'as war between nation states gives way to the less defined area of international terrorism, so the distinction between acts of war, man made accidents and natural disasters becomes less distinguishable' (Patrick 2003). This situation 'in turn leads to a panorama in which acts of God and events such as Chernobyl and September 11 together occupy an undifferentiated position at the center of the world stage'. Paul Virilio's museum of accidents, then, in this context is a twenty-first century equivalent to the 'traditional war memorial's "lest we forget".

Paul Virilio has taught us that in the 'crepuscular dawn' [6] of our twenty-first century modernities the attack and the accident are becoming indistinguishable. The 'art of the accident', or what has also elsewhere been termed 'apocalyptic art' [7], is one credible response to this dilemma. However, such aesthetic practice, a deconstructive play on the distinction between attack and accident, is certainly not sufficient to help us to theorize the new modernities which are catching up with the various new and old capitalisms on offer around the globe. It leaves us, strangely, exhibiting a kind of ghoulish fascination [8] with the effects of the failure of systems; 'rubber necking' at the art gallery and the accident museum or tuning in with compassionless glee to the reports in the media of the latest road crash statistics, a state of mind where 'what people watch above all on TV are the weekend's road accident figures, the catastrophes' [9] (Baudrillard 2004a:61). Or, as Virilio claims [10], (Virilio 2005a:111) 'elsewhere begins here'.

\section{Endnotes}

1. As the call for papers put it for an Economic and Social Research Council (ESRC) Conference on Urban Vulnerability and Network Failure, organized by the Center for Sustainable Urban Regional Futures (SURF) at the University of Salford in the United Kingdom in April 2004.

2. Mike Gane (Gane, 2003:162) suggests that one trend in French social theory is indeed a 'shift towards the sacred' Virilio's trajectory over the years epitomizes this shift (Redhead 2004a) and is shared to some extent by his friend Luce Irigaray, Virilio's main long term connection to French feminism.
3. The acknowledgement for the inspiration for this reversible phrase goes to Virilio and Lotringer (2005).

4. For example, a conference entitled 'The Dromocratic Condition' at the University of Newcastle, Newcastle, UK, March 2005, followed the concept of 'the dromocratic condition' coined by British academic John Armitage, who has, in recent years, done much to publicize Virilio in the English speaking world and in particular showcased Virilio's book City of Panic in the journal Cultural Politics (Armitage 2005). The call for papers for the conference explicitly posited the idea, for subsequent discussion, of the Virilio influenced 
'dromocratic condition' taking over today from JeanFrancois Lyotard's 1980s notion of the 'postmodern condition' (Lyotard 1984).

5. Originally entitled in French Ce Qui Arrive, the English version of the book was published by Verso (Virilio 2002) with the more ' $9 / 11$ ' oriented title Ground Zero to fit in with its miniseries of books on September 11, 2001. Virilio actually has a little more to say about $9 / 11$ and its effects on urban culture in later work (Virilio 2005a).

6. Virilio and Lotringer 2002 is the source for this pregnant, enigmatic phrase.

7. For instance, a film like director Danny Boyle's Twenty Eight Days Later (screenplay by fiction writer Alex Garland), released a year after September 11, 2001, but filmed in 2001, has been tarred with this brush, along with other contemporary art and culture; see New Statesman, July 21, 2003.

8. The health warning which Virilio's work should bear is evident in this rather weird fascination with the accident, catastrophe or disaster or spectacular failure of modernity. The distinct problem of this position can be seen when you compare the similar fascination exhibited in the twentieth century by a distinctly unpalatable thinker like Ernst Junger. Virilio (2005a:114, 117) himself has quoted and cited Junger in his often bizarre referencing system (Virilio 2005a:143).

9. The words are those of Virilio's friend and countryman Jean Baudrillard in conversation with Francois L'Yvonnet. Paul Hegarty (Hegarty 2004) argues quite correctly, in an excellent book on Jean Baudrillard, that Paul Virilio is the theorist closest to Baudrillard's ideas (though he points out that they differ in subtle ways) and that Virilio is the one person he has engaged with most over the years. As Mike Gane (Gane 2003) notes, for instance, Virilio worked with Baudrillard on the journal Traverses between 1975 and 1990. Baudrillard contributes one of the other books in Verso's miniseries on September 11, 2001 (Baudrillard: 2004b). Both Baudrillard (2005) and Virilio (2005a) are now published by Berg in England. For a critical comparison of Baudrillard and Virilio, and their intertwined histories, see Redhead, 2004a and Redhead, 2004b.

10. The original French version of Virilio's book Ville Panique (City of Panic in Julie Rose's English translation, Virilio 2005a) had the subtitle 'Ailleurs Commence Ici' which was dropped in the English version.

\section{References}

Ali, Tariq (2005) Rough Music. London: Verso.

Armitage, John. 2005. "Escape from Alphaville: Introducing Paul Virilio's City of Panic." Cultural Politics 1(3).

----...2001. Virilio Live: Selected Interviews. London: Sage.

-.---. 2000. Paul Virilio: From Modernism to Hypermodernism and Beyond. London: Sage.

Baudrillard, Jean. 2005. The Intelligence of Evil or the Lucidity Pact. Oxford: Berg.

-----. 2004a. Fragments. London: Routledge.

----- 2004b. The Spirit of Terrorism. $2 \mathrm{~d}$ ed. London: Verso.

Conley, Verena Andermatt. 2005. 'Virilio's Electronic Derive'. Cultural Politics 1(3).

Cubitt, Sean. 2001. Simulation and Social Theory. London: Sage.

Der Derian, James, ed. 1998. The Virilio Reader. Oxford: Blackwell.

Featherstone, Mike and Scott Lash, eds. 1999. Spaces of Culture. London: Sage.

Gane, Mike. 2003. French Social Theory. London: Sage.

Hegarty, Paul. 2004. Jean Baudrillard: Live Theory. London: Continuum.

Kureishi, Hanif. 2005. The Word and the Bomb. London: Faber. Patrick, Keith. 2003. “The Century of Fear." Contemporary 47(8).

Lyotard, Jean-Francois. 1984. The Postmodern Condition: A Report on Knowledge. Minneaoplis: University of Minnesota Press.

Redhead, Steve, ed., 2004a. The Paul Virilio Reader. Edinburgh: Edinburgh University Press.
----.. 2004b. Paul Virilio: Theorist for an Accelerated Culture. Edinburgh: Edinburgh University Press.

Ruthen, Malise. 2002. A Fury for God. London: Granta.

Sokal, Alan and Jean Bricmont. 2003. Intellectual Impostures: Postmodern Philosophers' Abuse of Science. $2 \mathrm{~d}$ ed. London: Profile Books.

Thrift, Nigel. 2005. "Panicsville: Paul Virilio and the Aesthetic of Disaster." Cultural Politics 1(3).

Urry, John, 2003. Global Complexity. Polity: Cambridge.

Virilio, Paul and Sylvere Lotringer. 2005. The Accident of Art.

New York: Semiotext(e).

Virilio, Paul. 2005a. City of Panic. Oxford: Berg.

----. 2005b. Negative Horizon. London: Continuum.

-----. 2005c. 'Democracy of Emotion'. Cultural Politics 1(3).

-.--.. 2005d. "Cold Panic." Cultural Politics 1(3).

-----. 2003. Unknown Quantity. London: Thames and Hudson.

Virilio, Paul and Sylvere Lotringer. 2002. Crepuscular Dawn. New York and Los Angeles: Semiotext(e).

Virilio, Paul. 2002. Ground Zero. London: Verso.

-----. 2000. A Landscape of Events. Cambridge, MA: MIT Press.

Virilio, Paul, in conversation with Petit, Philippe.1999. Politics of the Very Worst. New York: Semiotext(e).

Virilio, Paul, in conversation with Oliveira, Carlos. 1996. "The Silence of the Lambs." Apres Coup. 